\title{
Rate of Melting of Partly Reduced Iron Pellets into Iron Melt*
}

\author{
By Akira SATO,** Kazuo KASAHARA, ** Ryuichi NAKAGAWA, ** Shiro YOSHIMATSU,** \\ Akira FUKUZAWA,** Tsuyoshi OZAKI, ,** Yoshie IWAI, ${ }^{* *}$ Yasumitsu FUKUZAWA** \\ and Tatsuro MITSUI**
}

\section{Synopsis}

The rate of melting of partly reduced iron pellets into iron melt was determined by measuring the amount of $\mathrm{CO}$ gas evolved. The effect of composition of pellets as well as those of temperature and carbon content of iron melt on the melting rate have been investigated. The following results were obtained:

(1) The apparent activation energy for melting of reduced iron pellets containing 0, 10, 20 and $40 \% \mathrm{Fe}_{2} \mathrm{O}_{3}$ was $33 \mathrm{kcal} / \mathrm{mol}$.

(2) Without the presence of molten slag on the iron melt, the maximum melting rates of pellets containing 10,20 and $40 \% \mathrm{Fe}_{2} \mathrm{O}_{3}$ were determined by using the iron melts of about 3.3, 3.0 and $2.5 \%$ carbon, respectively.

(3) The melting rate was proportional to -0.5 power of the $\mathrm{Fe}_{2} \mathrm{O}_{3}$ content in the range of $15 \sim 60 \% \mathrm{Fe}_{2} \mathrm{O}_{3}$. The rate was larger than the value at $2 \sim 10 \% \mathrm{Fe}_{2} \mathrm{O}_{3}$ and was smaller than the value above $70 \%$ $\mathrm{Fe}_{2} \mathrm{O}_{3}$.

(4) By the addition of 2 to $5 \%$ of $\mathrm{CaO}, \mathrm{CaCO}_{3}$ or $\mathrm{C}$ the melting rate of pellets was increased, while it was decreased markedly by the addition of $\mathrm{Al}_{2} \mathrm{O}_{3}$ or $\mathrm{SiO}_{2}$. In the cases of simultaneous addition of $\mathrm{CaO}$ and $\mathrm{SiO}_{2}\left(\mathrm{CaO} / \mathrm{SiO}_{2}=I\right)$ and addition of pre-fused slag having low melting point, the melting rate was slightly decreased, but their contents in pellets should be below $15 \%$.

\section{Introduction}

The research work on the continuous iron- and steel-making process from directly reduced iron or pre-reduced iron ore (called reduced iron hereafter) has been carried on at NRIM since 1974. It was shown that the melting rate of reduced iron pellets with high reduction degree into iron melt was greatly affected by the residual oxygen content, content and composition of gangue in pellets, carbon content and temperature of iron melt. ${ }^{1-4)}$

In this report, the melting rate of partly reduced iron pellets into iron melt has been determined by measuring the amount of $\mathrm{CO}$ gas evolved by the reduction of iron oxide in pellets with carbon in the iron melt. The effects of the above mentioned factors on the rate of melting have been investigated.

\section{Experimental}

Figure 1 shows a schematic diagram of the experimental apparatus with a Tammann furnace for controlled atmospheric melting. Volume of $\mathrm{CO}$ gas evolved was measured by an integrating gas meter. Because the measurable range of this meter was 5 to $300 \mathrm{l} / \mathrm{h}$, nitrogen gas was flowed at the rate of $60 \mathrm{l} / \mathrm{h}$ in order to detect the end of reduction.

By the combined use of the electric power source equipped with silicon circuit rectifiers and the temperature controller with a PR-6/30 thermocouple, the iron melt was kept at a pre-determined temperature within $\pm 5^{\circ} \mathrm{C}$. The temperature of iron melt was also measured with a $\mathrm{Pt}-\mathrm{Pt} / \mathrm{Rh}$ thermocouple immersed into the melt.

The $\mathrm{Fe}-\mathrm{C}$ alloy used was prepared by melting the mixture of electrolytic pure iron and electrode carbon powders in a graphite crucible with an induction furnace. A graphite or a alumina crucible was used for the preparation of iron melts of saturated carbon and various carbon contents. Crucibles were of $55 \mathrm{~mm}$ ID and $190 \mathrm{~mm}$ long. Weight of the iron melt used was about $1.5 \mathrm{~kg}$ whose volume was about a half of the crucible. Carbon content of the iron melt was determined by the chemical analysis of sample sucked up with quartz tube.

Partly reduced iron pellets of cylindrical shape were made by pressing the mixture of Höganäs iron powders, $\mathrm{Fe}_{2} \mathrm{O}_{3}$ [special grade chemical reagent (C.A.)] and other additives in a die with a 60-t oil press. The weight, the horizontal sectional area and the forming pressure of pellets were $70 \mathrm{~g}, 7 \mathrm{~cm}^{2}$ and $4 \mathrm{t} / \mathrm{cm}^{2}$, respectively. Pulverized additives were $\mathrm{Al}_{2} \mathrm{O}_{3}$ (first grade C.A.), $\mathrm{CaCO}_{3}$ (first grade C.A.), $\mathrm{CaO}(95.2 \% \mathrm{CaO}), \mathrm{SiO}_{2}\left(99.8 \% \mathrm{SiO}_{2}\right)$, electrode carbon $(98 \% \mathrm{C})$ and prefused slag $\left(43 \% \mathrm{CaO}, 48 \% \mathrm{SiO}_{2}\right.$, $9 \% \mathrm{Al}_{2} \mathrm{O}_{3}$ ). Contents of $\mathrm{Fe}_{2} \mathrm{O}_{3}$ and additives were 10 $20-40 \%$ and $2-5-10 \%$, respectively. Density of pellet was calculated from the weight and the height measured by a direct-vision balance and a micrometer, respectively.

The experimental procedure was as follows: $\mathrm{Fe}-$ $\mathrm{C}$ alloy was melted in a nitrogen atmosphere and held at an experimental temperature for $30 \mathrm{~min}$. The surface of the iron melt was cleaned by scraping and then $\mathrm{Fe}_{2} \mathrm{O}_{3}$ was added. After stirring of the iron melt, samples for chemical analysis were taken out

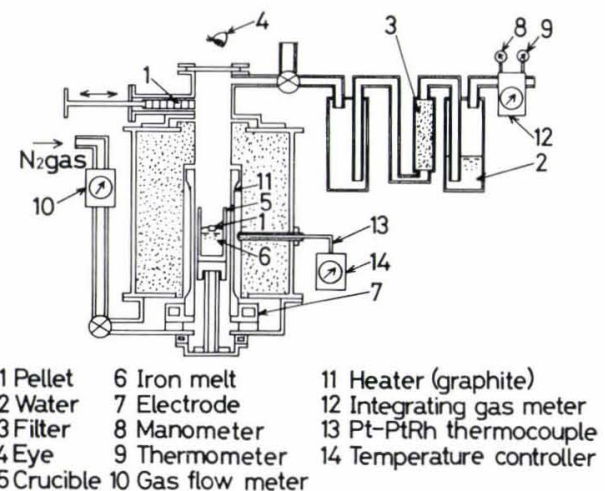

Fig. 1. Schematic diagram of experimental apparatus

* Originally published in Tetsu-to-Hagané, 65 (1979), 195, in Japanese. English version received December 11, 1978.

** National Research Institute for Metals, Nakameguro, Meguro-ku, Tokyo 153. 
by suction. From $5 \mathrm{~min}$ after closing the window of furnace, the flow rate of nitrogen gas was recorded every $30 \mathrm{sec}$ for $2 \mathrm{~min}$. A pellet previously charged in the apparatus was dropped onto the melt. From that moment, the gas flow rate was recorded every 5 sec. Volume of $\mathrm{CO}$ gas evolved was obtained by subtracting the nitrogen gas flow rate from the gas flow rate measured. The time required for melting of pellets was determined on the basis of the diagrams showing the relation between the amount of $\mathrm{CO}$ gas evolved and the elapse of time. The melting rate (g/sec) was obtained by dividing $70 \mathrm{~g}$ by the time required for melting (sec).

The reproducibility was determined by the results of repeated runs at each experimental condition.

\section{Results}

Figure 2 shows the dependence of the amount of $\mathrm{CO}$ gas evolved on the content of $\mathrm{Fe}_{2} \mathrm{O}_{3}$ in pellets added onto the iron melt saturated with carbon at $1520^{\circ} \mathrm{C}$. The maximum $\mathrm{CO}$ gas evolving rate $\left(\mathrm{Nm}^{3} /\right.$ $\mathrm{sec}$ ) increased with increasing content of $\mathrm{Fe}_{2} \mathrm{O}_{3}$ except for $5 \% \mathrm{Fe}_{2} \mathrm{O}_{3}$. For $5 \% \mathrm{Fe}_{2} \mathrm{O}_{3}$ the melting rate was very rapid, and at the same time, the gas evolving rate was also very rapid. Volume of $\mathrm{CO}$ gas evolved reached almost to the theoretical value for pellets of $2 \sim 40 \% \mathrm{Fe}_{2} \mathrm{O}_{3}$, but for pellets of $50 \sim 70 \%$ $\mathrm{Fe}_{2} \mathrm{O}_{3}$ the value obtained was slightly lower than the theoretical one. This was confirmed to be due to the $\mathrm{CO}_{2}$ gas simultaneously evolved in a small quantity when the $\mathrm{CO}$ gas evolving rate was very rapid. That is, the amount of $\mathrm{CO}_{2}$ gas evolved was about $1 \%$ according to the measurement by a simple $\mathrm{CO}_{2}$ gas meter with the accuracy of $0.5 \%$ for the pellet of $70 \% \mathrm{Fe}_{2} \mathrm{O}_{3}$, although $\mathrm{CO}_{2}$ gas could not be detected for pellets of $2 \sim 30 \% \mathrm{Fe}_{2} \mathrm{O}_{3}$.

Figure 3 shows the effect of the $\mathrm{Fe}_{2} \mathrm{O}_{3}$ content in pellets on the time necessary for melting into the iron melt saturated with carbon at $1520^{\circ} \mathrm{C}$. The melting rate showed a maximum at about $2 \% \mathrm{Fe}_{2} \mathrm{O}_{3}$ and decreased linearly with increasing content of $\mathrm{Fe}_{2} \mathrm{O}_{3}$ in the range of $15 \sim 60 \% \mathrm{Fe}_{2} \mathrm{O}_{3}$. The melting rate of pellets containing above $70 \% \mathrm{Fe}_{2} \mathrm{O}_{3}$ seemed to decrease markedly.

Figure 4 shows the dependence of the time necessary for melting on the temperature of iron melt saturated with carbon and on the $\mathrm{Fe}_{2} \mathrm{O}_{3}$ content in pellets. The melting rate increased with increasing temperature and with decreasing content of $\mathrm{Fe}_{2} \mathrm{O}_{3}$. However, it is shown that the rate at $1620^{\circ} \mathrm{C}$ is nearly the same as that at $1570^{\circ} \mathrm{C}$.

Figure 5 shows the dependence of the amount of $\mathrm{CO}$ gas evolved on the temperature of iron melt saturated with carbon and on the $\mathrm{Fe}_{2} \mathrm{O}_{3}$ content in pellets. The maximum $\mathrm{CO}$ gas evolving rate increased with increasing temperature and with increasing content of $\mathrm{Fe}_{2} \mathrm{O}_{3}$.

Figure 6 shows the dependence of the time necessary for melting on the carbon content in iron melt at $1520^{\circ} \mathrm{C}$ and on the $\mathrm{Fe}_{2} \mathrm{O}_{3}$ content in pellets. The melting rate of pellets without $\mathrm{Fe}_{2} \mathrm{O}_{3}$ increased with increasing carbon content. But the melting rates of

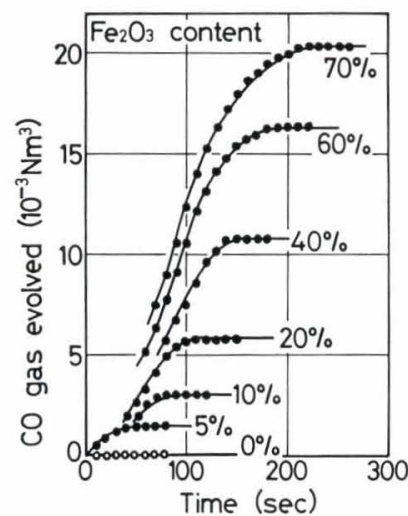

Fig. 2. Dependence of $\mathrm{CO}$ gas evolved on $\mathrm{Fe}_{2} \mathrm{O}_{3}$ content in pellet added onto iron melt saturated with carbon at $1520^{\circ} \mathrm{C}$

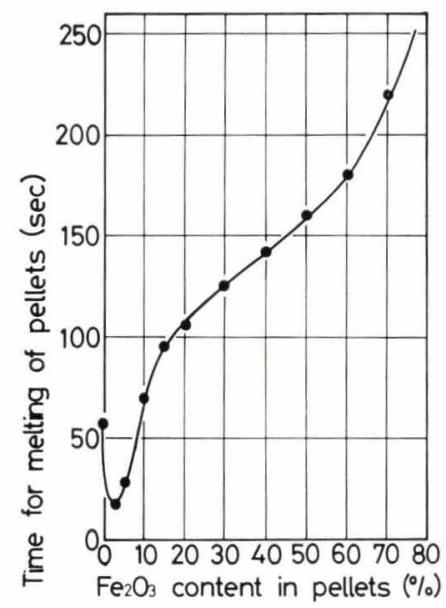

Fig. 3. Effect of $\mathrm{Fe}_{2} \mathrm{O}_{3}$ content in pellets on their time for melting into iron melt saturated with carbon at $1520^{\circ} \mathrm{C}$

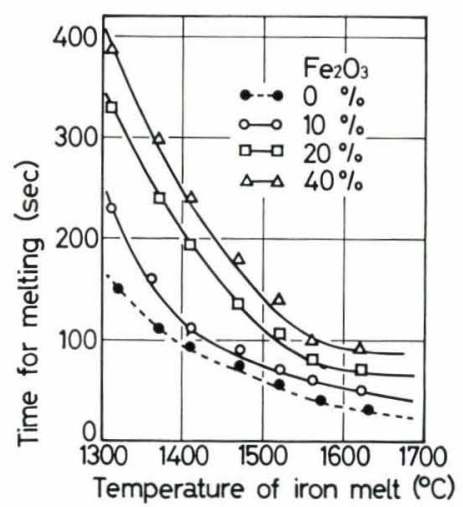

Fig. 4. Dependence of the time for melting on temperature of iron melt saturated with carbon and on $\mathrm{Fe}_{2} \mathrm{O}_{3}$ content in pellets

pellets containing 10,20 and $40 \% \mathrm{Fe}_{2} \mathrm{O}_{3}$ showed maxima at about $3.3,3.0$ and $2.5 \% \mathrm{C}$, respectively. The rate decreased remarkably for the iron melt of less than $1 \% \mathrm{C}$. The rates measured in $\mathrm{Al}_{2} \mathrm{O}_{3}$ crucibles for the samples of high carbon contents were rather lower than those obtained in graphite crucibles.

Figure 7 shows the dependence of the amount of 


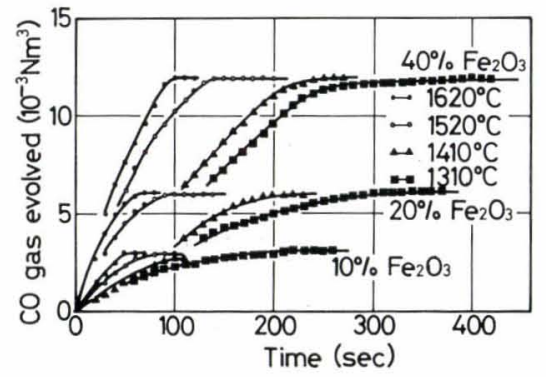

Fig. 5. Dependence of $\mathrm{CO}$ gas evolved on temperature of iron melt saturated with carbon and on $\mathrm{Fe}_{2} \mathrm{O}_{3}$ content in pellets

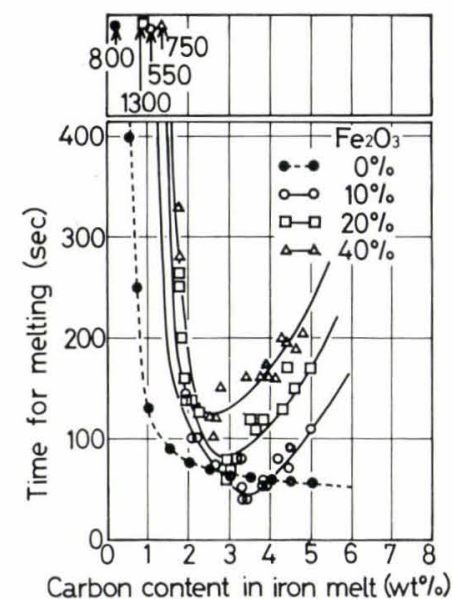

Fig. 6. Dependence of the time for melting on carbon content in iron melt at $1520^{\circ} \mathrm{C}$ and on $\mathrm{Fe}_{2} \mathrm{O}_{3}$ content in pellets

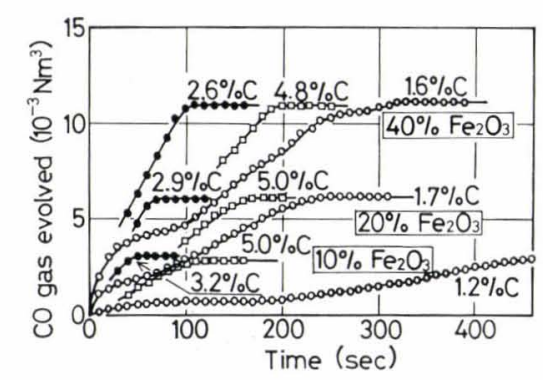

Fig. 7. Dependence of $\mathrm{CO}$ gas evolved on carbon content in iron melt at $1520^{\circ} \mathrm{C}$ and on $\mathrm{Fe}_{2} \mathrm{O}_{3}$ content in pellets

$\mathrm{CO}$ gas evolved on the carbon content in iron melt at $1520^{\circ} \mathrm{C}$ and on the $\mathrm{Fe}_{2} \mathrm{O}_{3}$ content in pellets. The $\mathrm{CO}$ gas evolving rate fluctuated widely in the region of low carbon content as in the case of the pellet of $40 \% \mathrm{Fe}_{2} \mathrm{O}_{3}$ for the iron melt of $1.6 \% \mathrm{C}$.

Figures 8 to 12 show the effects of $\mathrm{CaO}, \mathrm{CaCO}_{3}$, carbon, $\mathrm{CaO}-\mathrm{SiO}_{2}$ mixture $\left(\mathrm{CaO} / \mathrm{SiO}_{2}=1\right)$, prefused slag, $\mathrm{SiO}_{2}$ and $\mathrm{Al}_{2} \mathrm{O}_{3}$ in pellets on the time necessary for melting into the iron melt saturated with carbon at $1520^{\circ} \mathrm{C}$, repectively. With increasing $\mathrm{CaO}$, $\mathrm{CaCO}_{3}$ or carbon content, the melting rate increased, showed maxima and then decreased, as shown in Fig. 8 to 10 . In the case of $\mathrm{CaO}-\mathrm{SiO}_{2}$ mixture or slag, the melting rate decreased it slightly as shown in Fig. 11, but for $\mathrm{SiO}_{2}$ or $\mathrm{Al}_{2} \mathrm{O}_{3}$ decreased markedly as shown in Fig. 12. The pellets containing more than

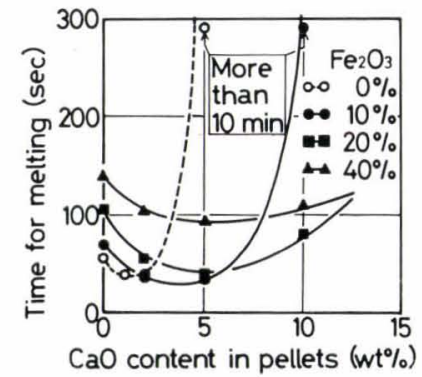

Fig. 8. Effect of $\mathrm{CaO}$ and $\mathrm{Fe}_{2} \mathrm{O}_{3}$ content in pellets on their time for melting into iron melt saturated with carbon at $1520^{\circ} \mathrm{C}$

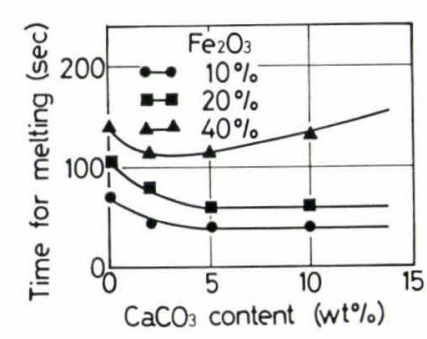

Fig. 9 .

Effect of $\mathrm{CaCO}_{3}$ and $\mathrm{Fe}_{2} \mathrm{O}_{3}$ content in pellets on their time for melting into iron melt saturated with carbon at $1520^{\circ} \mathrm{C}$

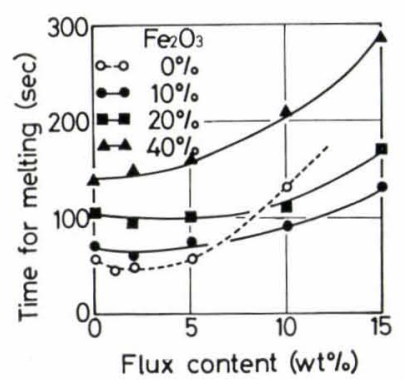

(a)

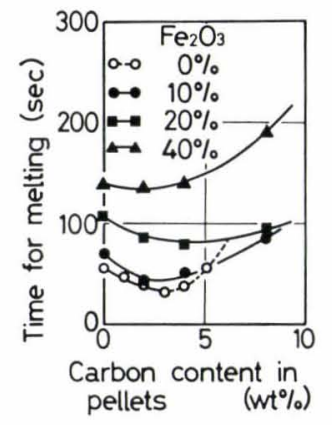

Fig. 10.

Effect of carbon and $\mathrm{Fe}_{2} \mathrm{O}_{3}$ content in pellets on their time for melting into iron melt saturated with carbon at $1520^{\circ} \mathrm{C}$

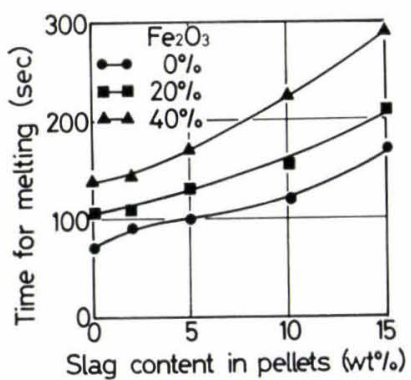

(b)
Fig. 11. Effect of (a) flux, (b) slag and $\mathrm{Fe}_{2} \mathrm{O}_{3}$ content in pellets on their time for melting into iron melt saturated with carbon at $1520^{\circ} \mathrm{C}$ flux $\left(\mathrm{CaO} / \mathrm{SiO}_{2}=1\right)$

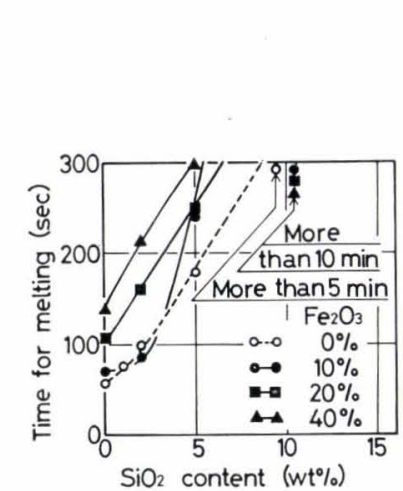

(a)

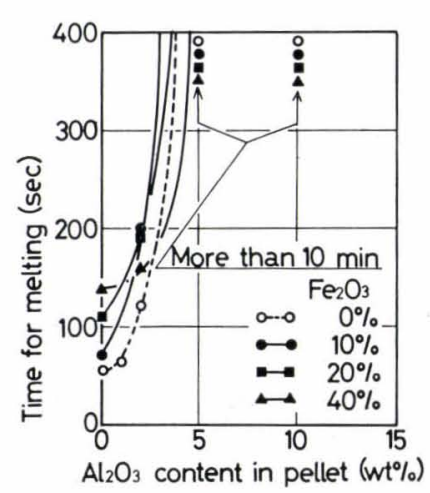

(b)
Fig. 12. Effect of (a) $\mathrm{SiO}_{2}$, (b) $\mathrm{Al}_{2} \mathrm{O}_{3}$ and $\mathrm{Fe}_{2} \mathrm{O}_{3}$ content in pellets on their time for melting into iron melt saturated with carbon at $1520^{\circ} \mathrm{C}$ 
$5 \% \mathrm{Al}_{2} \mathrm{O}_{3}$ floated on the iron melt for more than 10 min keeping cylindrical shape. The $\mathrm{CO}$ gas evolving rate of pellets containing $2 \% \mathrm{Al}_{2} \mathrm{O}_{3}$ fluctuated widely for the elapse of time similarly to the case of iron melt of low carbon content.

\section{Discussion}

It is considered that the kinetics of melting of a partly reduced iron pellet into iron melt consists of the following four main processes: (1) the heat transfer from the iron melt to the pellet, (2) the transfer of carbon from the iron melt to the melting interface, (3) the transfer of iron from the pellet to the iron melt, and (4) the reduction of iron oxides in the pellet by carbon in the iron melt. Processes from (1) to (3) are similar to those for melting of steel scrap in an iron bath and for a highly reduced iron pellet on the iron melt. ${ }^{5-13)}$ In this research, the process of (4) is considered to play an important role.

Researches on the reduction of iron oxides by carbon in iron melt reported so far are as follows: Dancy ${ }^{14)}$ reported that there was a pressure increase from $100 \mathrm{~mm} \mathrm{Hg}$ when iron oxides ( $\mathrm{FeO}, \mathrm{Fe}_{3} \mathrm{O}_{4}$ ) weighing $0.5 \mathrm{~g}$ were dropped onto the carbon saturated iron melt weighing $50 \mathrm{~g}$ in a rotating $\mathrm{MgO}$ crucible, and that the apparent activation energies obtained by neglecting the area of the reaction interface were 43 and $37 \mathrm{kcal} / \mathrm{mol}$ for $\mathrm{FeO}$ and $\mathrm{Fe}_{3} \mathrm{O}_{4}$, respectively. MacRae ${ }^{15}$ ) obtained the pressure increase from 2 torr to 600 torr when $\mathrm{Fe}_{2} \mathrm{O}_{3}$ sample of cylindrical shape weighing $3 \mathrm{~g}$ was dropped onto the carbon saturated iron melt weighing $600 \mathrm{~g}$ in a graphite crucible. The apparent activation energies obtained by neglecting the area of the reaction interface were 27 and $44 \mathrm{kcal} / \mathrm{mol}$ for 60 and 480 torr, respectively. Since the melting rate and the apparent activation energies changed with the variation of initial pressure, the rate was considered to be determined by the mixed steps of complex chemical reactions and diffusion processes. Lloyd et al. ${ }^{16)}$ reported that a pressure increase from 200 to $300 \mathrm{mmHg}$ was observed when $\mathrm{Fe}_{2} \mathrm{O}_{3}$ weighing $0.710 \mathrm{~g}$ was dropped onto the iron melt weighing 180 to $200 \mathrm{~g}$ in an $\mathrm{Al}_{2} \mathrm{O}_{3}$ crucible. Measuring the area of reaction interface between the iron oxide assumed to be liquid and the iron melt with a planimeter, the activation energy of $56 \mathrm{kcal} /$ mol was obtained. The rate determining step of the process was considered to be the diffusion of carbon in the case of the iron melt below $0.2 \mathrm{wt} \% \mathrm{C}$ and the mixed step of the diffusion of carbon and the chemical reaction for the iron melt of $0.2 \mathrm{wt} \% \mathrm{C}$ or above. Because the rate of preheated sample was almost the same as that of cold one, and because the activation energy of the process was higher than that of the heat transfer, the heat transfer was not considered to be the rate determining step.

In this experiment, it was observed that pellets of $40 \% \mathrm{Fe}_{2} \mathrm{O}_{3}$ reacted with carbon in iron melt in the solid state. Therefore, it was impossible to measure the area of reaction interface from the top. Accordingly, the apparent activation energies were obtained by neglecting the area of the interface. Figure
13 shows the relation between $\log v$ and $1 / T$, where $v$ is the melting rate $(\mathrm{g} / \mathrm{sec})$ calculated from the weight of pellets $(70 \mathrm{~g})$ and the time necessary for melting (sec), and $T$ is the temperature of iron melt $\left({ }^{\circ} \mathrm{K}\right)$. The same apparent activation energy of $33 \mathrm{kcal} /$ mol was obtained for pellets containing $0,10,20$ and $40 \% \mathrm{Fe}_{2} \mathrm{O}_{3}$. This value can be regarded as nearly the same as that obtained by Dancy or MacRae. Though the activation energy for a pellet containing $0 \% \mathrm{Fe}_{2} \mathrm{O}_{3}$ was the same as that for a pellet containing $40 \% \mathrm{Fe}_{2} \mathrm{O}_{3}$, the melting rate of a pellet containing $0 \% \mathrm{Fe}_{2} \mathrm{O}_{3}$ was confirmed to be rate-determined by the heat transfer. That is, in order to confirm the result obtained by Lloyd et al. that the reduction rate was not rate-determined by the heat transfer, the melting rate was measured after pellets had been preheated to the temperature of melting. Namely, the pellets were suspended by a $\mathrm{Pt}$ wire of $0.5 \mathrm{~mm}$ diameter just above the iron melt for $10 \mathrm{~min}$. The iron melt was saturated with carbon and its temperature was $1520^{\circ} \mathrm{C}$. The times necessary for melting of pellets containing $0,10,20$ and $40 \% \mathrm{Fe}_{2} \mathrm{O}_{3}$ were $13,65,95$ and $125 \mathrm{sec}$, respectively. The melting rate of pellets containg $0 \% \mathrm{Fe}_{2} \mathrm{O}_{3}$ increased remarkably, but the increment of the melting rate of pellets containing $\mathrm{Fe}_{2} \mathrm{O}_{3}$ was at most $10 \%$. Therefore, as reported by Lloyd et al. ${ }^{16)}$ the melting rate of pellets containing $\mathrm{Fe}_{2} \mathrm{O}_{3}$ was not rate-determined by the heat transfer.

On the other hand, because the iron melt used was saturated with carbon and was stirred by $\mathrm{CO}$ bubbles, and because the activation energy for the diffusion of carbon in the carbon saturated iron melt was much lower than $33 \mathrm{kcal} / \mathrm{mol}$, the diffusion of carbon in iron melt can not be considered to be the rate determining step. Accordingly, the reduction would be remained as the rate determining step for pellets containing $\mathrm{Fe}_{2} \mathrm{O}_{3}$. The difference between the apparent activation energy obtained in this research work and the true one obtained by Lloyd et al. ${ }^{\mathbf{1 6})}$ may be attributable to the evaluation of area of the reaction interface. This must be confirmed by detailed experiments in future.

Figure 14 shows the relation between $\log v$ and $\log (\% \mathrm{C}$ in iron melt), where $v$ is the melting rate mentioned above. Below the carbon per cent of the maximum melting rate, the melting rate is propor-

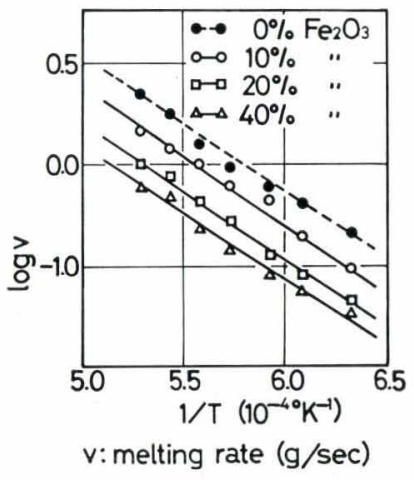

Fig. 13. Relation between $\log v$ and $(1 / T)$ 


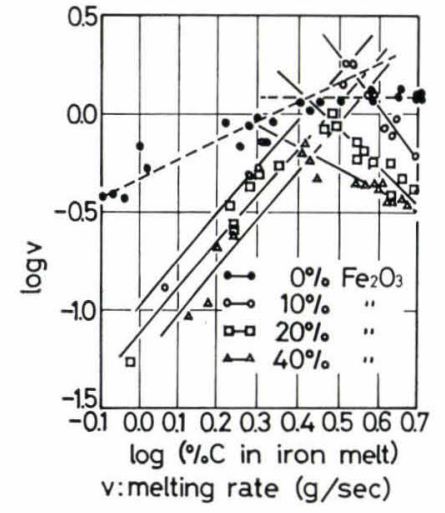

Fig. 14. Relation between $\log v$ and $\log (\% \mathrm{C}$ in iron melt)

tional to 0.96 and 2.4 powers of the carbon per cent for pellets containing $0,10,20$ and $40 \% \mathrm{Fe}_{2} \mathrm{O}_{3}$, respectively. The proportionality of the melting rate of pellets containing $0 \% \mathrm{Fe}_{2} \mathrm{O}_{3}$ to the carbon content is similar to that of the melting of steel scrap into $\mathrm{Fe}-$ C alloy bath. ${ }^{5-13)}$ On the other hand, the proportionality of the melting rate of pellets containing $\mathrm{Fe}_{2} \mathrm{O}_{3}$ to 2.4 powers of the carbon content is considered to be due to the reduction of iron oxide. At the carbon per cent of the maximum melting rate, the stirring of the iron melt by $\mathrm{CO}$ bubbles was so vigorous that the iron melt was frequently spurted from the crucible. The reason why vigorous stirring is taken place is not known yet. Above the carbon per cent of the maximum melting rate, the melting rates of pellets containing $0,10,20$ and $40 \% \mathrm{Fe}_{2} \mathrm{O}_{3}$ were proportional to about $0,-2.6,-1.9$ and -1.1 powers of the carbon per cent, respectively. But the reason that the proportionality is valid is not clarified either.

Figure 15 shows the relation between the $\mathrm{Fe}_{2} \mathrm{O}_{3}$ content in pellets and the melting rate into iron melt saturated with carbon at $1520^{\circ} \mathrm{C}$. The melting rate is proportional to -0.5 power of the $\mathrm{Fe}_{2} \mathrm{O}_{3}$ content of pellets in the range of $15 \%$ to $60 \% \mathrm{Fe}_{2} \mathrm{O}_{3}$. A remarkable increase in the rate at $2 \sim 10 \% \mathrm{Fe}_{2} \mathrm{O}_{3}$ would be due to the stirring by $\mathrm{CO}$ bubbles. A decrease in the melting rate of pellets contining above $70 \% \mathrm{Fe}_{2} \mathrm{O}_{3}$ may be due to the decrease in the reaction rate of liquid iron oxides. ${ }^{15)}$

Figure 16 shows the effect of additives in pellets on the heat required for melting at $1520^{\circ} \mathrm{C}$. The heat was obtained by the thermodynamic and thermochemical calculations. ${ }^{17,18)} \mathrm{CaO}, \mathrm{SiO}_{2}$ or $\mathrm{Al}_{2} \mathrm{O}_{3}$ increase the heat and $\mathrm{CaO}-\mathrm{SiO}_{2}$ mixture decreases it slightly. By adding $10 \%$ of $\mathrm{CaCO}_{3}$ or carbon, the heat is increased about $20 \%$. In the case of 2 to $5 \%$ addition of $\mathrm{CaO}, \mathrm{CaCO}_{3}$ or carbon, the melting rate and the heat are also increased. Therefore, the heat has a little effect on the melting rate.

The increase of the melting rate by the addition of $\mathrm{CaO}$ may be the same as that reported by Takahashi et al. ${ }^{19)}$ The increase of the melting rate by the addition of $\mathrm{CaCO}_{3}$ would be attributable to the stirring by $\mathrm{CO}_{2}$ gas bubbles brought about by the decomposition of $\mathrm{CaCO}_{3}$. The increase of the melting rate by

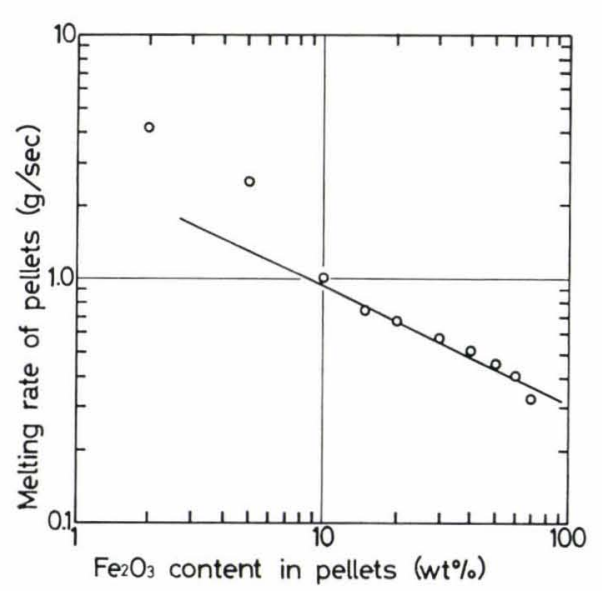

Fig. 15. Relation between $\mathrm{Fe}_{2} \mathrm{O}_{3}$ content in pellets and their melting rate into iron melt saturated with carbon at $1520^{\circ} \mathrm{C}$

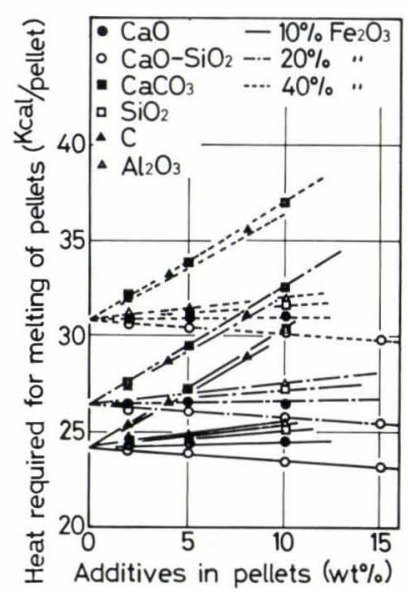

Fig. 16. Effect of additives in pellets on their heat required for melting

the addition of carbon would be due to the formation of eutectic of $\mathrm{Fe}-4.3 \% \mathrm{C}$ and the reaction between solid $\mathrm{Fe}_{2} \mathrm{O}_{3}$ and solid carbon. In order to produce pellets of high melting rate practically, the followings should be taken into consideration. Because of the reaction of $\mathrm{CaO}$ in pellets with moisture and $\mathrm{CO}_{2}$ in air, the pellets collapsed in a few days. Therefore, in order to increase the rate, $\mathrm{CaCO}_{3}$ should be added instead of $\mathrm{CaO}$. Addition of $5 \% \mathrm{CaCO}_{3}$ would be proper as it does not increase the heat required for melting greatly. Because the pellets added $5 \% \mathrm{C}$ decreased their strength markedly, the addition of $3 \%$ C would be proper.

Though $\mathrm{CaO}-\mathrm{SiO}_{2}$ mixture or prefused slag had a little effect on the rate in the range up to $10 \%$ addition, the pellets were wettable by the iron melt when the molten slag was not present on the iron melt. Therefore, the apparent melting rate was considered to decrease slightly because the area of melting interface increased. When the addition of slag was more than $15 \%, \mathrm{Fe}_{2} \mathrm{O}_{3}$ would melt into the molten slag. As a result of this the melting rate would be decreased remarkably.

The reason why $\mathrm{Al}_{2} \mathrm{O}_{3}$ or $\mathrm{SiO}_{2}$ decreased the rate extremely would be due to the formation of the slag 
of a high melting point at the melting interface as reported in the previous report. ${ }^{2)}$

Fluctuations of the $\mathrm{CO}$ gas evolving rate at low carbon content in iron melt would be due to the stagnation of the reaction owing to the lack of carbon transfer. On the other hand, fluctuations of the CO gas evolving rate of pellets added $2 \% \mathrm{Al}_{2} \mathrm{O}_{3}$ would be due to the accumulation of $\mathrm{Al}_{2} \mathrm{O}_{3}$ at the melting interface.

Philbrook et al. ${ }^{20-22)}$ reported that the reduction of iron oxide in molten slag was very slow. The molten slag is necessary to stabilize the arc when pellets are melted in an arc furnace. Therefore, the research into the effect of molten slag upon the melting rate of reduced iron pellets into iron melt is very important, and will be carried out in future.

\section{Conclusion}

The rate of melting of partly reduced iron pellets made of iron powders, $\mathrm{Fe}_{2} \mathrm{O}_{3}$ powders and pulverized additives was determined by measuring the amount of $\mathrm{CO}$ gas evolved. The effects of the composition of pellets as well as temperature and carbon content of iron melt on the rate of melting have been investigated. The following results were obtained:

(1) The apparent activation energy for melting of reduced iron pellets containing 0, 10, 20 and $40 \% \mathrm{Fe}_{2} \mathrm{O}_{3}$ was $33 \mathrm{kcal} / \mathrm{mol}$. The rate determining step is considered to be the heat transfer and the reduction of pellets charged with and without $\mathrm{Fe}_{2} \mathrm{O}_{3}$.

(2) When molten slag was not present on iron melt, the maximum melting rate of pellets containing 10,20 and $40 \% \mathrm{Fe}_{2} \mathrm{O}_{3}$ were determined by using the iron melts of about $3.3,3.0$ and $2.5 \% \mathrm{C}$.

(3) Below the carbon content which showed the maximum melting rate, the melting rate was proportional to 0.96 and 2.4 powers of the carbon content for pellets charged with and without $\mathrm{Fe}_{2} \mathrm{O}_{3}$.

(4) The melting rate of pellets into the iron melt saturated with carbon at $1520^{\circ} \mathrm{C}$ was proportional to -0.5 power of the $\mathrm{Fe}_{2} \mathrm{O}_{3}$ content in the range of 15 to $60 \% \mathrm{Fe}_{2} \mathrm{O}_{3}$. The rate was greater than the value at 2 to $10 \% \mathrm{Fe}_{2} \mathrm{O}_{3}$ and was smaller than the value in the range above $70 \% \mathrm{Fe}_{2} \mathrm{O}_{3}$.

(5) By the addition of 2 to $5 \%$ of $\mathrm{CaO}, \mathrm{CaCO}_{3}$ or carbon, the rate of melting was increased, while it was decreased remarkably by the addition of $\mathrm{Al}_{2} \mathrm{O}_{3}$ or $\mathrm{SiO}_{2}$. In the cases of simultaneous addition of
$\mathrm{CaO}$ and $\mathrm{SiO}_{2}\left(\mathrm{CaO} / \mathrm{SiO}_{2}=1\right)$ and addition of prefused slag having low melting point, the rate was slightly decreased in the range up to $5 \%$, but their contents in pellets should be below $15 \%$.

\section{REFERENCES}

1) S. Yoshimatsu, R. Nakagawa, A. Sato, A. Fukuzawa, T. Ozaki, K. Kasahara, Y. Fukuzawa and T. Mitsui: Tetsuto-Hagané, 62 (1976), S445.

2) A. Sato, R. Nakagawa, S. Yoshimatsu, A. Fukuzawa, T. Ozaki, K. Kasahara, Y. Fukuzawa and T. Mitsui: Tetsuto-Hagané, 64 (1978), 385.

3) S. Yoshimatu, R. Nakagawa, A. Sato, A. Fukuzawa, T. Ozaki, K. Kasahara, Y. Fukuzawa and Y. Iwai: Tetsu-toHagané, 63 (1977), S20.

4) A. Fukuzawa, K. Kasahara, Y. Fukuzawa, Y. Iwai, R. Nakagawa, S. Yoshimatsu, A. Sato and T. Ozaki: Tetsuto-Hagané, 63 (1977), S21.

5) R. G. Olsson, V. Koump and T. F. Perzak: Trans. AIME, 233 (1965), 1654.

6) R. D. Pehlke, P. D. Goodell and R. W. Dunlap: Trans. AIME, 233 (1965), 1420.

7) M. Kosaka and A. Minowa: Tetsu-to-Hagané, 52 (1966), 1429 .

8) R. Jeshar and E. Millies: Arch. Eisenhiuttenw, 37 (1967), 283.

9) M. Kosaka and S. Minowa: Tetsu-to-Hagané, 53 (1967), 983.

10) K. Mori and H. Nomura: Tetsu-to-Hagané, 55 (1969), 347.

11) H. Nomura and K. Mori: Tetsu-to-Hagané, 55 (1969), 1134.

12) J. Szekerly, Y. K. Chung and J. W. Hlinka: Met. Trans., 3 (1972), 2825.

13) Y. Kawai: Kinetics of Ferrous Metallurgy, Nihon Kogyo Shinbunsha, Tokyo, (1976), 140.

14) T. E. Dancy: JISI, 169 (1951), No. 9, 17.

15) D. R. MacRae: J. Metals, 17 (1965), 1391.

16) G. W. Lloyd, D. R. Young and L. A. Baker: Ironmaking and Steelmaking, 2 (1975), No. 1, 49.

17) O. Kubachewski and E. L. Evans: Metallurgical Thermochemistry, (1958).

18) J.F. Elliott, M. Gleiser and V. Ramakrishna: Thermochemistry for steelmaking, Addison-Wesley Publishing Co. Ltd., London, (1963).

19) R. Takahashi, M. Ishii and I. Takahashi: Tetsu-to-Hagané, 63 (1977), S456.

20) W. O. Philbrook and L. D. Kirkbride: Trans. AIME, 206 (1956), 351 .

21) S. K. Tarby and W. O. Philbrook: Trans. AIME, 239 (1967), 1005.

22) P. M. Shuriugin, V. N. Voronekov, V. I. Kriuk and V. V. Revedtzov: Izv. VUZav, Cher. Met,, (1965), No. 2, 23. 